УДК 159.9.072.43

\title{
ВОЗРАСТ РЕБЕНКА КАК МОДУС ДЕТСКО-РОДИТЕЛЬСКИХ ОТНОШЕНИЙ
}

\author{
Кириленко Ирина Николаевна
}

В статье представлен анализ возраста в качестве модуса детскородительских отношений. Такая позиция предполагает рассмотрение возраста ребенка как фактора изменения особенностей детско-родительских отношений. Как известно, на детско-родительские отношения при поступлении ребенка в школу начинают влиять и новые условия его жизни. Как возникновение, так и разрешение кризисов детско-родительских отношений связано с их постоянным изменением с течением возраста ребенка и неизбежным отделением ребенка от родителей. Таким образом, детско-родительские отношения получают определенную специфику своего развития в зависимости от возраста их субъектов. Автором анализируются классические исследования, посвященные проблематике развития ребенка и переживанию возрастных кризисов. Вместе с тем автор обращается к современным социальным реалиям, влияющим на поведение ребенка и векторы детско-родительских отношений, которые рассматриваются с точки зрения оченочно-эмоционального компонента, развития игровой и сочиальной активности ребенка. Автор делает значимый вывод о том, что кризис дошкольного развития может проходить в достаточно мягкой форме. Фактором, определяющим особенности протекания кризиса, являются детско-родительские отношения. Наличие психологической поддержки ребенка, эмоциональной близости с ним, проявление искреннего интереса к успехам и неудачам ребенка, забота и внимание со стороны родителей - способствуют тому, что переживание кризиса становится максимально «безболезненным». Это гармонизирует детско-родительские отношения и позитивно влияет на развитие семьи как социального института. Соответственно, в современных условиях требуется новый поход к оптимизации личностного развития ребенка.

Это становится возможным при рассмотрении возраста ребенка как фактора, определяющего тип, характер и специфику детско-родительских отношений.

Ключевые слова: детско-родительские отношения, возраст, эмоции, кризис, кризисные явления, ситуативно-деловое общение, «семизвездье симптомов», социальные роли, семья, взаимодействие. 
Новые возможности для развития детско-родительских отношений открываются в период раннего детства ребенка. Важным событием с конца первого года жизни становится постепенное обретение ребенком навыков самостоятельного передвижения. Е. О. Смирнова, изучая детско-родительские отношения, среди их особенностей назвала свойственную им способность к изменению в зависимости от возраста ребенка [7]. Во взаимодействии с родителями у него начинает складываться ситуативно-деловое общение. Данная форма общения представляет собой практическое, деловое сотрудничество родителей и ребенка по поводу действий с предметами. Согласно Д. Б. Эльконину, в этом возрасте взрослый для ребенка - образец для подражания, руководитель, контролер, источник эмоциональной поддержки [9]. Для укрепления детско-родительских отношений со стороны родителей важны внимательность и понимание ребенка. Именно такое общение составляет основу детско-родительского взаимодействия вплоть до 3 лет. В раннем детстве контакт родителей и ребенка приобретает опосредованность предметом и действием с ним. Родители воспринимаются ребенком, прежде всего, как соучастники предметной и игровой деятельности. Для ребенка родители так же значимы, как образец для подражания, как источник оценки знаний и умений, а также его эмоциональной поддержки, подкрепления достижений. Значительное внимание в исследованиях детско-родительских отношений уделяется рассмотрению их эмоционально-оценочной стороны. При этом, в частности, доказано, что детско-родительские отношения характеризуются сильными эмоциональными проявлениями со сторон детей и родителей [6]. Для укрепления детско-родительских отношений со стороны родителей важны внимательность и понимание ребенка. Со стороны ребенка данные отношения поддерживаются: активным использованием речи; действиями по привлечению к себе внимания; требованиями соучастия взрослого в его делах; открытостью, любовью, эмоциональным откликом на ласку; чуткостью к оценкам родителей и стремлением к перестройке своего поведения в зависимости от их поведения.

Взросление ребенка сопровождается изменениями детско-родительских отношений, которые подвергаются влиянию свойственного раннему возрасту обособления личных желаний и обнаружения взрослого в качестве важнейшего лица ситуации.

В этот период жизни ребенок впервые оценивает родителей, и эта оценка не всегда оказывается в пользу последних. Внутренней необходимостью для ребенка становится противопоставление себя родителям. Благодаря этому у него начинает формироваться воля, проявления автономии (независимости, самостоятельности), снижается потребность в опеке со стороны родителей, появляется стремление делать собственный выбор. Феномен «Я 
сам» знаменует психологическое отделение ребенка от родителей и распад прежней ситуации социального развития.

Уже к трем годам ребенок приобретает способность отделять себя от окружающих, воспринимать себя в качестве субъекта действия и проводить сравнение с другими людьми. Первый кризис в построении детскородительских отношений находится в непосредственной связи с кризисом развития личности трех лет.

Л. С. Выготскому принадлежит описание особенностей, которые он представил как «семизвездье симптомов», переживаемого ребенком кризиса [3]:

- негативизм ребенка проявляется через стремление сделать что-то вопреки предложению взрослого, даже вразрез с собственным желанием; негативная реакция возникает в ответ на предложение, идущее от взрослого;

- упрямство обнаруживается в стремлении ребенка настоять на чем-то только потому, что он этого потребовал, отстаивается свое первоначальное решение;

- строптивость, свойственная в этот период ребенку, направляется им в целом против норм воспитания, образа жизни, сложившегося до трех лет;

- своеволие реализуется через стремление все делать самостоятельно, воплощать инициативу собственного действия;

- протест-бунт состоит в том, что ребенок входит в состояние войны и конфликта практически со всеми окружающими;

- симптом обесценивания проявляется в том, что ребенок ругает, дразнит и обзывает родителей;

- деспотизм ребенка заключается в его требовании к родителям делать все то, что он требует.

Возрастной кризис 3-х лет может рассматриваться в качестве первого кризиса детско-родительских отношений.

Наш опрос родителей, дети которых переступили возраст 3 года жизни ( $\mathrm{N}=750)$, показал, что кризисность этого периода пережила значительная часть респондентов ( $n=560)$, однако их оценка силы кризиса оценивается по-разному. Из них по 7-балльной шкале:

- высоким баллом его оценили 148 испытуемых;

- средним баллом - 306 испытуемых;

- низким баллом - 306 испытуемых.

Ключевыми характеристиками данного кризиса детско-родительских отношений по итогам беседы с родителями назовем следующие позиции сторон:

- желание ребенка перевести детско-родительские отношения на новый уровень их развития, в котором ему предоставляется больше 
самостоятельности от родителей и более значительная роль в построении этих отношений;

- стремление родителей сохранить опеку над ребенком, оградить его от опасностей, передать собственный опыт поведения.

Полученные нами результаты совпадают с научными выводами, сделанными В. Н. Голубевым относительно юношеского возраста, но вполне применимыми уже к периоду раннего детства [4]. В возрасте 3 лет обнаруживаются процессы явного взросления ребенка. Для родителей - это достаточно «драматичный» период внутрисемейной жизни. Как отмечает исследователь, они не в состоянии быстро приспособиться к произошедшим в детях переменам и перестроить свое поведение в соответствии с новой социально-психологической ситуацией общения. Это фиксируется детьми. В результате дети пытаются достичь автономии в рамках семейной структуры, а родители еще не готовы им ее предоставить. Это делает взаимоотношения между детьми возраста 3 лет и их родителями потенциально конфликтными. Родители в значительной части это понимают. Опрошенные нами родители сошлись во мнении, что в этот период требуется значительная перестройка детско-родительских отношений. В рамках их гармонизации и содействия развития ребенка родители призваны дать ему большую самостоятельность, а также возможность понять различие между «хочу» и «должен». Кризисные явления развития личности 3 года жизни протекают значительно мягче, если детско-родительские отношения выстраиваются на относительно демократической основе.

Окончание периода раннего детства характеризуется смещением интересов ребенка к миру «общественных взрослых». Отношение к взрослому начинает выстраиваться на основе вычленения присущей ему социальной роли («мама вообще», «папа вообще», воспитатель детского сада, водитель маршрутки, врач и т. д.). Всякий взрослый, включая родителей, теперь воспринимается ребенком как носитель конкретных образцов действий и устанавливаемых социальных отношений (мягкости и строгости, руководства и подчинения, справедливости и несправедливости). В свою очередь, подобные изменения не могут не сказаться на особенностях построения родителями отношений со своим ребенком. Они получают возможность устанавливать в отношении с ребенком более четкие требования, снижать опеку над ним, наделять определенными обязанностями.

В основе построения детско-родительских отношений в семьях с ребенком дошкольного возраста, продолжающегося с 3 до 6 лет, можно назвать новую ситуацию его развития, связанную с выходом за рамки семьи, окружения близких для него людей. В дошкольном возрасте детско-родительские отношения поддерживаются свойственной ребенку потребностью в общении 
с взрослым, углубляемой его стремлением к сопереживанию и взаимопониманию. Более того, выстраивая отношения в семье, ребенок стремится достичь во взаимодействии с родителями общности взглядов. Развитию взаимоотношений с родителями способствует обогащение его речи выразительными жестами, эмоциями, вокализациями. Расширившиеся речевые возможности ребенка позволяют ему не только обогатить круг своего общения, но и значительно углубить обсуждаемую с другими людьми проблематику. Согласно М. И. Лисиной, в немалой степени этому способствует оформление у ребенка дошкольного возраста двух новых форм общения внеситуативно-познавательного и внеситуативно-личностного [5]. На поднимаемые им вопросы относительно самого широкого круга проблем он требует серьезного отношения родителей, а к себе - уважения. Отсутствие требуемого по отношению к себе поведения со стороны родителей рождает у него повышенную обидчивость, которая негативно отражается на построении детско-родительских отношений.

Развитию навыков построения взаимодействия не только с родителями, но и с другими взрослыми и сверстниками, способствует освоение ребенком дошкольного возраста игровой деятельности. Осваивая и погружаясь в игру, ребенок получает возможность:

- разобраться в сфере человеческих отношений, смыслов и задач деятельности;

- развить у себя стремления к общественно значимой и оцениваемой деятельности;

- активизировать оформление произвольности поведения и психических процессов, а также идеального плана сознания;

- преодолеть эгоцентризм своего познания;

- становления эмоциональной саморегуляции поведения;

- стимулировать развитие своей речи.

Значимой для нашего исследования особенностью рассматривается возрастание ценности для дошкольника своих сверстников как субъектов взаимодействия. Если в начале дошкольного возраста (3-4 года) ровесник оставался для ребенка прежде всего участником совместной практической деятельности, то уже к 5-7 годам в глазах ребенка он приобретает индивидуальность, становится значимым лицом общения, обгоняет взрослого по частоте взаимодействия. В результате к нему начинает проявляться личностное отношение. Особенно ценимыми качествами сверстников дошкольник называет мягкость, внимание, эмоциональную отзывчивость, уравновешенность. В качестве объективных условий, поддерживающих дружеские контакты со сверстниками, для дошкольника выступают: проживание по соседству, посещение одной группы детского сада, одних спортивных занятий и пр. 
Возрастание значимости для дошкольника отношений со сверстниками не означает исчезновение значимости для него отношений с родителями. Так же, как и для раннего детства, для дошкольного детства характерны:

- преувеличение силы и могущества родителя, вера в его неограниченные возможности, достижения;

- преувеличение знаний, компетентности и мудрости родителя [1].

В этот период детско-родительские отношения могут способствовать следующим изменениям ребенка:

- построению им абриса картины мира; для этого ребенок задает родителям многочисленные вопросы, позволяющие ему объяснить и упорядочить в его воображении окружающий мир;

- формированию широкого спектра мотивов поведения и их иерархии;

- приобретению мотивами характера обобщенных намерений, которые начинают осознаваться ребенком;

- усвоению им начальных этических интенций;

- образованию зачатков произвольного поведения, складывающегося под влиянием ориентирующих образцов, поступающих со стороны родителей;

- развитию самосознания и самооценки, позволяющих, в том числе, оценивать собственные умения, реализовывать практическую деятельность;

- приобретению начальных умений ориентироваться в собственных чувствах и переживаниях;

- появлению рассудительности ребенка;

- осознанию им правил, как некоторых установлений, которые необходимо обязательно исполнять.

На родителей в данном периоде жизни ребенка возлагается необходимость вдумчивого ответа на вопросы ребенка, предоставления ему достаточного спектра образцов поведения и тактичного управления его поведением.

Не всегда семьи способны установить детско-родительские отношения, позитивно отражающиеся на ребенке. О. Г. Хайбуллина, изучавшая особенности детско-родительских отношений в семьях, где воспитывается дошкольник, пришла к выводу, что в них преобладает тип родительского отношения «Симбиоз» [8]. Такой тип отношений характеризуется тем, что матери не устанавливают психологическую дистанцию между собой и ребенком, стараются всегда быть ближе к нему, удовлетворять его основные разумные потребности, оградить от неприятностей. При этом они постоянно ощущают тревогу за ребенка, ребенок им кажется маленьким и беззащитным. Подобные детско-родительские отношения, как указывает исследователь, формируют у детей дошкольного возраста восприятие семьи и семейных отношений как тревожных.

Завершение дошкольного возраста, как установлено в возрастной психологии, связано с возникновением кризиса развития личности ребенка, 


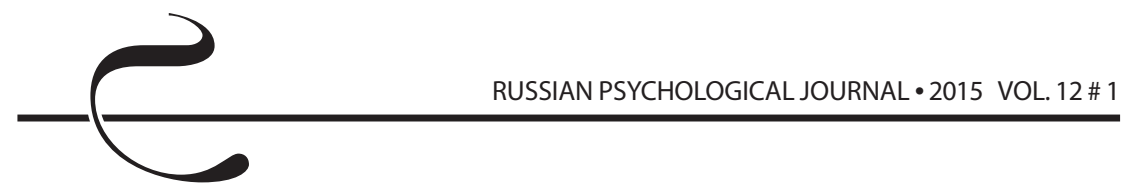

проявляющегося в утрате им детской непосредственности. Одновременно обнаруживаются некоторые кризисные проявления в функционировании детско-родительских отношений.

В отличие от кризиса детско-родительских отношений 3-х лет, кризис дошкольного детства, как показал опрос родителей $(\mathrm{N}=750)$, переживается ими значительно легче.

Кризисным этот период назвали 398 человек. Из них:

- только 36 родителей отнесли рубеж дошкольного детства к уровню высококризисного периода в детско-родительских отношениях;

- 194 человека - к среднекризисному периоду;

- 168 человек вообще не рассматривают этот период жизни ребенка в качестве кризисного, приводящего к изменениям в детско-родительских отношениях.

Вместе с тем опрос родителей показал, что на построении детскородительских отношений отражаются следующие особенности поведения ребенка этого возраста:

- возникновение паузы, которая разделяет обращение к ребенку и появление с его стороны ответной реакции;

- появление элементов оспаривания ребенком необходимости выполнить родительскую просьбу, или ее исполнение отсрочивается во времени;

- проявление непослушания в виде отказов от привычных дел и обязанностей;

- желание скрытой хитростью нарушить сложившиеся правила;

- демонстрирование своей «взрослости» через манерничанье и всяческое ее подчеркивание;

- обострение внимания ребенка к своему внешнему облику и одежде, появление стремления не выглядеть «как маленький».

Крайними формами кризиса дошкольного возраста могут выступить проявляющиеся в отношениях с взрослыми упрямство ребенка, его требовательность, капризы, постоянные напоминания об обещаниях, обостренная реакция на критику, ожидание похвалы со стороны взрослых за любую мелочь, незначительные действия ребенка.

Итак, мы делаем вывод, согласно которому кризис дошкольного возраста, в целом, проходит в достаточно мягкой форме и не наносит существенного урона построению детско-родительских отношений. Дошкольник продолжает сохранять заинтересованность в отношениях с родителями, стремится их расширить и укрепить. В беседы с родителями он стремится ввести новые темы, позволяющие ему расширить представления о мире и о своем месте в нем. В этот период ребенок нуждается в том, чтобы родители разъяснили ему причины выдвигаемых перед ним требований и напоминали о сделанных 
поручениях. Важно также, чтобы они поддерживали прилагаемые им усилия похвалой и уверенностью в его способностях, давали возможность выполнения самостоятельных действий.

Наличие родительской поддержки обеспечивает сохранение человеком физического и психического здоровья, создает ощущение благополучия и удовлетворенности жизнью, тогда как ее отсутствие приводит к снижению качества жизни и к трудностям при преодолении сложных ситуаций, даже при наличии других ресурсов совладания [10]. По мнению Дж. Боулби, условием здорового психоэмоционального развития, помимо автономии от родителей, является сохранение с ними эмоциональной близости [2].

\section{Литература}

1. Алексеева А. С., Меновщиков В. Ю. Семейная психотерапия в центре психологической помощи. - М.: Изд-во НИИ семьи, 1998.

2. Боулби Дж. Создание и разрушение эмоциональных связей. - М., Академический проект, 2004.

3. Выготский Л. С. Воображение и творчество в детском возрасте. - СПб.: Союз, 1997. - 96 с.

4. Голубев В. Н., Девятых С. Ю. Особенности детско-родительских отношений в старшем юношеском возрасте // Известия Смоленского государственного университета. - 2010. - № 2. - С. 293-302.

5. Лисина М. И. Общение, личность и психика ребенка. Под ред. А. Г. Рузской; вст. ст. А. Г. Рузской. 2-е изд. - М.: Изд-во Московского психологосоциального института; Воронеж: НПО «МОДЭК», 2001. - 384 с.

6. Смирнова Е. О. Особенности общения и отношения к сверстникам у дошкольников, растущих без семьи // Вопросы психического здоровья детей и подростков. - 2002. - № 2. - С. 19-25.

7. Смирнова Е. О., Соколова М. В. Структура и динамика родительского отношения в онтогенезе ребенка // Вопросы психологии. - 2007. № 2. - С. 57-68.

8. Хайбуллина О.Г. Особенности детско-родительских отношений в семьях детей дошкольного возраста // Вестник института семьи. - 2010. - № 5. С. 95-100.

9. Эльконин Д. Б. К проблеме периодизации психического развития в детском возрасте // Вопросы психического здоровья детей и подростков. 2004. - № 1. - C. 68-78.

10. Lunsky Y., Benson B. A. Perceived Social Support and Mental Retardation: A Social-Cognitive Approach // Cognitive Therapy and Research. - 2001. Vol. 25. - № 1 . 